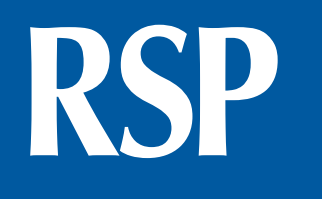

http://www.rsp.fsp.usp.br/

Revista de Saúde Pública

\title{
Factors associated with preventable infant death: a multiple logistic regression
}

\author{
Sandra Maria Cunha Vidal e Silva', Rogério Antonio Tuon', Livia Fernandes Probst", Brunna \\ Verna Castro Gondinho", Antonio Carlos Pereira"', Marcelo de Castro Meneghim"'", Karine Laura \\ Cortellazzi"', Glaucia Maria Bovi Ambrosano"II \\ 1 Prefeitura Municipal de Piracicaba. Secretaria Municipal de Saúde. Coordenação do Programa Pacto pela \\ Redução do Óbito Infantil. Piracicaba, SP, Brasil \\ " Universidade Estadual de Campinas. Faculdade de Odontologia de Piracicaba. Programa de Pós-Graduação \\ em Odontologia, Área de Concentração Saúde Coletiva. Piracicaba, SP, Brasil \\ III Universidade Estadual de Campinas. Faculdade de Odontologia de Piracicaba. Departamento de Odontologia Social. \\ Piracicaba, SP, Brasil
}

\section{ABSTRACT}

OBJECTIVE: To identify and analyze factors associated with preventable child deaths.

METHODS: This analytical cross-sectional study had preventable child mortality as dependent variable. From a population of 34,284 live births, we have selected a systematic sample of 4,402 children who did not die compared to 272 children who died from preventable causes during the period studied. The independent variables were analyzed in four hierarchical blocks: sociodemographic factors, the characteristics of the mother, prenatal and delivery care, and health conditions of the patient and neonatal care. We performed a descriptive statistical analysis and estimated multiple hierarchical logistic regression models.

RESULTS: Approximatelly $35.3 \%$ of the deaths could have been prevented with the early diagnosis and treatment of diseases during pregnancy and $26.8 \%$ of them could have been prevented with better care conditions for pregnant women.

Correspondence:

Glaucia Maria Bovi Ambrosano Departamento de Odontologia Social Faculdade de Odontologia de

Piracicaba - Unicamp

Av. Limeira, 901

Caixa Postal 52

13414-903 Piracicaba, SP, Brasil

E-mail: glaucia@fop.unicamp.br

Received: Jun 5, 2017

Approved: Aug 8, 2017

How to cite: Vidal e Silva SMC, Tuon RA, Probst LF, Gondinho BVC, Pereira AC, Meneghim MC, et al. Factors associated with preventable infant death: a multiple logistic regression. Rev Saude Publica. 2018;52:32.

Copyright: This is an open-access article distributed under the terms of the Creative Commons Attribution License, which permits unrestricted use, distribution, and reproduction in any medium, provided that the original author and source are credited.
CONCLUSIONS: The following characteristics of the mother are determinant for the higher mortality of children before the first year of life: living in neighborhoods with an average family income lower than four minimum wages, being aged $\leq 19$ years, having one or more alive children, having a child with low APGAR level at the fifth minute of life, and having a child with low birth weight.

DESCRIPTORS: Infant Mortality. Risk Factors. Socioeconomic Factors. Perinatal Care. Infant, Newborn, Diseases, prevention \& control. Prenatal Care. Cross-Sectional Studies. 


\section{INTRODUCTION}

Infant mortality is a classic indicator of the socioeconomic conditions of a country or region' Infant mortality rate is defined as the number of deaths of children under one year of age, per thousand live births, in the population living in a given geographical area, in the year under consideration. It consists of two components: the neonatal period, which estimates the risk of death in the first 27 days of life, and the post-neonatal period, which estimates the risk of death from 28 days to the end of the first year of life ${ }^{2}$.

While neonatal mortality is intrinsically related with the conditions of pregnancy, delivery, and the child's own physical integrity, post-neonatal mortality is more associated with socioeconomic and environmental conditions, with a predominance of infectious causes. In both components of infant mortality, however, an important share of responsibility is attributed to health services and social determinants of health. Adequate sanitary measures, access to health services, and good quality of care are factors that play a role in reducing infant mortality ${ }^{3}$.

The post-neonatal period showed greater decrease (50\%) compared to the neonatal period (death in the first 27 days of life), in which a reduction of 36.5\% was observed, from 2000 to $2006^{2}$. The prevalence of neonatal death still remains high, especially for the early neonatal component (up to six days), with the aggravating circumstance that most of these deaths are considered preventable ${ }^{2}$.

In Brazil, even with regional differences, important changes occurred in the health conditions of children in the last two decades. The infant mortality rate showed a significant reduction, with rates ranging from 21.1 (in 2000) to 15.3 (in 2011), corresponding to a decrease of $27.5 \%$. This was mainly due to the reduction in the mortality of children in the post-neonatal period. However, there was an increase in mortality in the neonatal period and markedly in the first week of life, that is, approximatelly $60 \%$ of the deaths occur in the early neonatal period ${ }^{5}$.

Therefore, the analysis of child mortality according to the basic cause of death is essential as it allows direct actions to be performed to avoid the initial causes of the process that leads to death ${ }^{6}$.

The study of preventable deaths is considered a methodological approach to assess the quality of health services, and its occurrence is considered an indicator of the potential shortcomings of the health system in the provision of the necessary care at the appropriate time ${ }^{7}$. High rates of avoidable infant deaths reflect difficulties in the access and quality of the health services offered to the population ${ }^{8}$.

Since the 1990s, approximately $60 \%$ of the infant deaths are concentrated in the first few days of life from complications in pregnancy, prenatal period, and delivery. These determinants associated with neonatal death reflect multifactorial influences such as the social status of the family, maternal characteristics, and access and quality of maternal and child care ${ }^{9}$.

The report of the National Commission on Social Determinants of Health highlights two aspects of inequities in health ${ }^{10}$ related with wealth distribution in the country and the deterioration in the relations of solidarity and trust among the population. Countries with high income inequalities have poor levels of social cohesion and political participation and invest less in social support networks, which are essential for the promotion and protection of health ${ }^{10}$.

Environmental conditions, the characteristics of the mother, and social relationships between population groups are also determining factors for the death of a child. Therefore, factors such as the age of the mother, interval between pregnancies, parity, low birth weight, sanitation, access to health centers, and other elements that are part of the life of a person such as 
housing, income, security, and education, are associated with child mortality 5 . Furthermore, the standard of living of a society is hard to be measured because of its complexity, since its social relationships encompass different behaviors and cultural values, as well as different political relations between persons and ethnic groups. These values depend on the time, place, and life course of each society ${ }^{11}$.

Therefore, the identification of pregnant women at higher risk, the reduction of organizational barriers in health services, and the increase of the access to family planning and early diagnosis of pregnancy are strategic actions to reduce the child mortality rate ${ }^{12}$. This research aimed to study preventable child mortality and its associated factors.

\section{METHODS}

This study was approved by a local Research Ethics Committee, with resolution 196/96 of the National Health Council, Brazilian Ministry of Health, under Process 129/2012.

This is an analytical cross-sectional study with preventable child mortality as dependent variable. Data were obtained from the Information System on Live Births (SINASC) and Information System on Mortality (SIM) ${ }^{13}$ in the period from 2005 to 2011, in the city of Piracicaba, state of São Paulo, Brazil. Technicians of the Municipal Database performed the link between the data from SINASC and SIM. The fields used for linking were the data on the identification of the mother ( full name, age, and address). Two files were made per year, in series from 2005 to 2011: one for preventable deaths (excluding other classifications) and another for live births, in which the death was marked in red. All the files of the variables of personal identification were removed, leaving only the variable of the neighborhood of residence of the mothers. Manual peer review was carried out by the technical officials of the municipality database.

The average income of the neighborhood of the mother was obtained from the 2010 IBGE Census $^{14}$. The variable of attachment for live births was the neighborhood of the mother.

Child deaths considered non-preventable were excluded from this study according to the classification criteria adopted by the State System of Data Analysis Foundation (SEADE), as well as the ones whose mothers did not live in Piracicaba ${ }^{15}$.

To compose the sample, 272 preventable deaths were selected after the exclusion of 88 non-preventable ones in a total of 360 registered deaths in the SIM in the studied period. To study live births (control group), from a population of 34,284 babies (SINASC), a sample was chosen from a systematic sampling of $1 / 8$ of this population, in which we obtained 50 births per month. A recorded number was drawn to start the selection, and from there, one case in every eight live births was systematically selected, composing a sample of 629 for each year studied, which amounted to 4,402 cases.

The sample size was determined assuming a 95\% confidence level, sampling error of 5\%, test power of at least $80 \%$, and significance level of $5 \%$. The independent variables were grouped into four hierarchical blocks according to the model proposed by Lima et al. ${ }^{16}$, organized in the levels: distal, intermediate I and II, and proximal in relation to the dependent variable. In this context, the distribution of the variables in each hierarchical block started with sociodemographic factors until comprising those with greater proximity to the outcome variable, as follows:

- Block I. Distal variables - sociodemographic characteristics of the mother: Education of the mother: none, from one to three years, from three to seven years, from eight to 11 years, 12 years or more. Profession of the mother: housewife, student, other. Race: white, black, yellow (Asian), mixed race. Average income in minimum wage in the neighborhood of the mother: up to 3.99 minimum wages, from four to 9.99 minimum wages, 10 or more minimum wages. 
- Block II. Intermediate variables I -characteristics of the mother: Age group of the mother: from 10 to 14 years old, from 15 to 19 years old, from 20 to 29 years old, from 30 to 39 years old, 40 years old or more. Number of children alive: zero, from one to three, four or more. Number of dead children: zero, one, two or more. Marital status of the mother: single, married, widowed, divorced.

- Block III. Intermediate variables II - Prenatal and delivery care: Type of pregnancy: singleton, twins, triplets or more. Type of delivery: vaginal birth, cesarean section, other. Number of prenatal care appointments: none, from one to three, from four to seven, seven or more.

- Block IV. Proximal variables - Health conditions of the newborn and neonatal care: Pregnancy duration in weeks: less than 28 weeks, from 28 to 37 weeks, from 37 to 40 weeks, 40 or more weeks. APGAR score (which assesses the vitality of the newborn in the first, fifth, and tenth minute of life) in the first minute of life: from 0 to 3 , from 4 to 7, from eight to 10. APGAR score in the fifth minute of life: from 0 to 3 , from 4 to 7 , from eight to 10. Birth weight (in g): less than 1,000 g, from 1,000 $\mathrm{g}$ to $1,499 \mathrm{~g}$, from 1,500 $\mathrm{g}$ to $2,499 \mathrm{~g}$, from $2,500 \mathrm{~g}$ to $3,999 \mathrm{~g}$, 4,000 $\mathrm{g}$ or more.

Initially, descriptive analyses were performed, which were followed by the estimation of hierarchical multiple logistic regression models with the PROC GENMOD procedure using the SAS statistical program, considering the binomial distribution and logistic link function. Variables had as permanence condition the $\mathrm{p} \leq 0.05$ model and the settings were evaluated according to the Quasi-Likelihood under Independence Model Criterion (QIC). All analyses were carried out in the SAS statistical program ${ }^{17}$.

\section{RESULTS}

Table 1 shows the frequency of preventable child deaths, considering the underlying causes of death and components of child mortality. Regarding the underlying causes of death, 272 deaths occurred in the studied period, of which $35.3 \%(\mathrm{n}=96)$ could have been avoided with adequate diagnosis and early treatment during pregnancy, $26.8 \%(n=73)$, with the appropriate care of the pregnant woman, $22.1 \%(n=60)$, with partnerships with other sectors (intersectoriality), $15.4 \%(\mathrm{n}=42)$, with the proper care of the woman during delivery, and $0.4 \%$ (one death), with immunoprevention. For components of child mortality, we observed that the higher frequency of deaths occurred in the early neonatal period (between zero to six days of life), with a total of 141 deaths (51.8\%). In the late neonatal period (from seven to 27 days), there were 48 deaths (17.6\%). The sum of child deaths that occurred from zero to 27 days ( $\mathrm{n}=189$ ) corresponds to the component "neonatal child mortality"; approximately $69.4 \%$ of the deaths happened during this particular period. In the post-neonatal period (from 28 to 364 days), we observed a percentage of $30.5 \%$, which corresponds to 83 deaths.

The frequency of variables regarding the sociodemographic aspects (distal level) and characteristics (intermediate level I) of the mother is shown in Table 2. At the distal level,

Table 1. Frequency distribution of variables related to children who died from potentially preventable causes. Piracicaba, state of São Paulo, Brazil, 2011.

\begin{tabular}{lccc}
\hline Variable & Category & Frequency & $\%$ \\
\hline & Reducible by immunoprevention & 1 & 0.4 \\
Cause of death & Reducible by adequate care for women during pregnancy & 73 & 26.8 \\
& Reducible by adequate care for women during labor & 42 & 15.4 \\
& Reducible by adequate actions of early diagnosis and treatment & 96 & 35.3 \\
Components of & Reducible by partnerships with other sectors & 60 & 22.1 \\
child mortality & Early neonatal death (0 to 6 days of life) & 141 & 51.8 \\
& Late neonatal death (from 7 to 27 days) & 48 & 17.6 \\
\hline
\end{tabular}


Table 2. Frequency distribution of variables regarding the sociodemographic characteristics (distal level) and personal characteristics (intermediate level I) of the mother. Piracicaba, state of São Paulo, Brazil, 2011.

\begin{tabular}{|c|c|c|c|c|c|}
\hline \multirow{3}{*}{ Variable } & \multirow{3}{*}{ Category } & \multicolumn{4}{|c|}{ Preventable child death } \\
\hline & & \multicolumn{2}{|c|}{ No } & \multicolumn{2}{|c|}{ Yes } \\
\hline & & Frequency & $\%$ & Frequency & $\%$ \\
\hline \multicolumn{6}{|c|}{ Block I - Distal level } \\
\hline \multirow{5}{*}{$\begin{array}{l}\text { Education level of the } \\
\text { mother }\end{array}$} & None & 8 & 88.8 & 1 & 11.1 \\
\hline & 1 to 3 years & 180 & 90.9 & 18 & 9.0 \\
\hline & 4 to 7 years & 1,090 & 92.8 & 84 & 7.1 \\
\hline & 8 to 11 years & 2,583 & 95.2 & 128 & 4.7 \\
\hline & 12 and more & 541 & 94.9 & 29 & 5.0 \\
\hline \multirow{3}{*}{ Profession of the mother } & Housewife & 1,802 & 94.0 & 115 & 6.0 \\
\hline & Student & 139 & 93.9 & 9 & 6.0 \\
\hline & Other paid jobs & 2,080 & 94.6 & 118 & 5.3 \\
\hline \multirow{4}{*}{ Race } & White & 3,245 & 94.3 & 193 & 5.6 \\
\hline & Black & 222 & 89.8 & 25 & 10.1 \\
\hline & Yellow (Asian) & 6 & 100.0 & 0 & 0.0 \\
\hline & Mixed race & 876 & 95.2 & 44 & 4.7 \\
\hline \multirow{3}{*}{$\begin{array}{l}\text { Average income of } \\
\text { neighborhood in } \\
\text { minimum wages }\end{array}$} & Zero to 3.99 & 1,486 & 92.9 & 112 & 7.0 \\
\hline & 4 to 10 & 2,559 & 94.9 & 136 & 5.0 \\
\hline & 10 or more & 298 & 95.8 & 13 & 4.1 \\
\hline \multicolumn{6}{|c|}{ Block II - Intermediate level I } \\
\hline \multirow{5}{*}{ Ageof the mother } & 10 to 14 years & 26 & 89.7 & 3 & 10.3 \\
\hline & 15 to 19 years & 617 & 92.1 & 53 & 7.9 \\
\hline & 20 to 29 years & 2,355 & 94.3 & 143 & 5.7 \\
\hline & 30 to 39 years & 1,328 & 95.6 & 61 & 4.4 \\
\hline & 40 or more & 76 & 89.4 & 9 & 10.6 \\
\hline \multirow{3}{*}{ Number of alive children } & Zero & 2,086 & 94.4 & 123 & 5.5 \\
\hline & 1 to 3 & 2,146 & 94.4 & 126 & 5.5 \\
\hline & 4 or more & 166 & 91.2 & 16 & 8.7 \\
\hline \multirow{3}{*}{ Number of dead children } & Zero & 4,100 & 94.7 & 228 & 5.2 \\
\hline & One & 247 & 91.4 & 23 & 8.5 \\
\hline & 2 or more & 49 & 83.0 & 10 & 16.9 \\
\hline \multirow{4}{*}{ Marital status } & Single & 1,524 & 93.5 & 106 & 6.5 \\
\hline & Married & 2,791 & 95.8 & 124 & 4.2 \\
\hline & Widow & 5 & 71.4 & 2 & 28.6 \\
\hline & Divorced & 80 & 93.0 & 6 & 7.0 \\
\hline
\end{tabular}

we observed that the percentage of child mortality decreased the higher the educational level of the mother. Among student mothers, the percentage of child death was 6.1\%, and among mothers who declared themselves as black, the percentage was $10.1 \%$. We also found that mortality increased with decreasing average income of the neighborhood of the mother. At the intermediate level I, $10.3 \%$ of the children whose mothers were aged between 10 and 14 years ended up dying; this percentage dropped as the mothers got older, reaching a mortality of $4.4 \%$ in the age group from 30 to 39 years old. Regarding the number of children alive, the highest percentage of death $(8.7 \%)$ was observed among mothers with four or more children alive. Among mothers who were pregnant for the first time (with zero children) and mothers with two or more dead children, the percentage of child death was $5.5 \%$ and $16.9 \%$, respectively, while among mothers who had no dead children, the percentage was $5.2 \%$. 
Table 3 presents the frequency of variables regarding prenatal and delivery care (intermediate level II) and the health conditions of the newborn and neonatal care (proximal level). Among the women pregnant with twins, the percentage of child death was $21.9 \%$, while among the ones with singleton pregnancy, the percentage was only $5.2 \%$. In vaginal birth, $6.7 \%$ of the children ended up dying, and in cesarean section, $4.7 \%$. The percentage of child death decreased as the number of medical appointments increased. At the proximal level, we observed that among children who were born in less than 28 weeks of gestational age, the percentage of child death was $81.6 \%$; those with gestational age between 28 and 36 weeks had a percentage of $60.4 \%$; those with gestational age between 37 and 41 weeks had a percentage of $12.6 \%$, and those with gestational age of 42 or more weeks, had a percentage of $2.5 \%$. For the group of children with APGAR score from zero to three in the first and fifth minute, the death percentage was $69.2 \%$ and $78.2 \%$, respectively. Among children with birth weight below $1,000 \mathrm{~g}$, the percentage of death was $86.3 \%$, and among those who were born weighing between $1,000 \mathrm{~g}$ and $1,500 \mathrm{~g}$, this value decreased to $56.9 \%$. For children who were born weighing between $2,500 \mathrm{~g}$ and $4,000 \mathrm{~g}$, death percentage was only $2.6 \%$.

Table 4 presents the estimated parameters of multiple hierarchical logistic regression models adjusted to describe the influence of the variables on the death of newborns in hierarchical levels. In model 1 (distal level), comprising the sociodemographic characteristics of the mother, only the variable "average income per family of the neighborhood of the mother"

Table 3. Frequency distribution of variables related to prenatal care and childbirth (intermediate level II) and the health of the newborn and neonatal care (proximal level). Piracicaba, state of São Paulo, Brazil, 2011.

\begin{tabular}{|c|c|c|c|c|c|}
\hline \multirow{3}{*}{$\begin{array}{l}\text { Variable } \\
\text { (Intermediate level II) }\end{array}$} & \multirow{3}{*}{ Category } & \multicolumn{4}{|c|}{ Preventable child death } \\
\hline & & \multicolumn{2}{|c|}{ No } & \multicolumn{2}{|c|}{ Yes } \\
\hline & & Frequency & $\%$ & Frequency & $\%$ \\
\hline \multicolumn{6}{|c|}{ Block III - Intermediate level II } \\
\hline \multirow{3}{*}{ Type of pregnancy } & Singleton & 4,303 & 94.7 & 239 & 5.2 \\
\hline & Twins & 96 & 78.0 & 27 & 21.9 \\
\hline & Triplets or more & 3 & 100.0 & 0 & 0 \\
\hline \multirow{3}{*}{ Type of delivery } & Vaginal & 1,528 & 93.2 & 110 & 6.7 \\
\hline & Caesarean section & 2,874 & 95.2 & 142 & 4.7 \\
\hline & Other & 0 & 0.0 & 15 & 100.0 \\
\hline \multirow{4}{*}{$\begin{array}{l}\text { Number of } \\
\text { prenatal visits }\end{array}$} & None & 26 & 76.4 & 8 & 23.5 \\
\hline & 1 to 3 & 147 & 80.7 & 35 & 19.2 \\
\hline & 4 to 6 & 742 & 90.2 & 80 & 9.7 \\
\hline & 7 or more & 3,484 & 96.9 & 109 & 3.0 \\
\hline \multicolumn{6}{|c|}{ Block IV - Proximal level } \\
\hline \multirow{3}{*}{$\begin{array}{l}\text { Duration of pregnancy } \\
\text { in weeks }\end{array}$} & 28 to 36 & 32 & 39.5 & 49 & 60.4 \\
\hline & 37 to 41 & 270 & 87.3 & 39 & 12.6 \\
\hline & 42 and more & 4,081 & 97.4 & 108 & 2.5 \\
\hline \multirow{3}{*}{$\begin{array}{l}\text { APGAR score in the first } \\
\text { minute }\end{array}$} & 0 to 3 & 36 & 30.7 & 81 & 69.2 \\
\hline & 4 to 7 & 332 & 85.5 & 56 & 14.4 \\
\hline & 8 to 10 & 3,824 & 97.8 & 85 & 2.1 \\
\hline \multirow{3}{*}{$\begin{array}{l}\text { APGAR score in the } \\
\text { fifth minute }\end{array}$} & 0 to 3 & 10 & 21.7 & 36 & 78.2 \\
\hline & 4 to 7 & 64 & 52.4 & 58 & 47.5 \\
\hline & 8 to 10 & 4,120 & 96.9 & 128 & 3.0 \\
\hline \multirow{5}{*}{$\begin{array}{l}\text { Weight of the } \\
\text { child at birth (g) }\end{array}$} & Less than 1,000 & 13 & 13.6 & 82 & 86.3 \\
\hline & $1,000 \mathrm{I}-1,499$ & 25 & 43.1 & 33 & 56.9 \\
\hline & $1,500 \mathrm{I}-2,500$ & 320 & 87.4 & 46 & 12.5 \\
\hline & $2,500 \mathrm{I}-4,000$ & 3,843 & 97.3 & 104 & 2.6 \\
\hline & 4,000 or more & 201 & 99.0 & 2 & 0.9 \\
\hline
\end{tabular}


Table 4. Estimated parameters of hierarchical multiple logistic regression models adjusted to describe the influence of the variables on child deaths. Piracicaba, state of São Paulo, Brazil. 2011.

\begin{tabular}{|c|c|c|c|c|c|c|c|c|c|c|c|c|}
\hline \multirow{2}{*}{ Variable } & \multicolumn{3}{|c|}{ Model 1} & \multicolumn{3}{|c|}{ Model 2} & \multicolumn{3}{|c|}{ Model 3} & \multicolumn{3}{|c|}{ Model 4 (Final model) } \\
\hline & Estimate & $\mathrm{SE}^{\mathrm{a}}$ & $\mathbf{p}$ & Estimate & SE & $\mathbf{p}$ & Estimate & SE & $\mathbf{p}$ & Estimate & SE & $\mathbf{p}$ \\
\hline Intercept & -1.91 & 0.01 & $<0.0001$ & -2.38 & 0.09 & $<0.0001$ & -2.49 & 0.10 & $<0.0001$ & 7.25 & 0.65 & $<0.0001$ \\
\hline
\end{tabular}

Average household income in the neighborhood

\begin{tabular}{|c|c|c|c|c|c|c|c|c|c|c|c|c|}
\hline Zero to 3.99 & $\operatorname{Ref}^{b}$ & & & Ref & & & Ref & & & Ref & & \\
\hline 4 to 10 & -086 & 0.09 & $<0.0001$ & -0.61 & 0.10 & $<0.0001$ & -0.64 & 0.09 & $<0.0001$ & -0.51 & 0.13 & $<0.0001$ \\
\hline 10 or more & -1.20 & 0.23 & $<0.0001$ & -0.88 & 0.23 & 0.0001 & -0.87 & 0.24 & 0.0003 & -0.98 & 0.33 & 0.0030 \\
\hline \multicolumn{13}{|c|}{ Intermediate level I } \\
\hline \multicolumn{13}{|l|}{ Age group } \\
\hline$\leq 19$ years old & & & & 0.61 & 0.10 & $<0.0001$ & 0.68 & 0.11 & $<0.0001$ & 0.60 & 0.14 & $<0.0001$ \\
\hline 20 to 39 years old (ref) & & & & Ref & & & Ref & & & Ref & & \\
\hline$<40$ years old & & & & 0.48 & 0.30 & 0.1081 & 0.52 & 0.31 & 0.0924 & 0.40 & 0.31 & 0.1968 \\
\hline
\end{tabular}

Alive children

Zero (ref)

Ref

1 to $3 \quad 0.11$

4 or more

0.68

$0.10 \quad 0.2364$

0.13

$0.10 \quad 0.1797$

0.34

$0.11 \quad 0.0028$

Dead children

$0.22 \quad 0.0016$

0.72

0.20

0.0003

1.05

0.21

$<0.0001$

\begin{tabular}{|c|c|c|c|c|c|c|c|c|c|}
\hline \multicolumn{10}{|l|}{ Dead children } \\
\hline Zero (ref) & Ref & & & & & & Ref & & \\
\hline One & 0.35 & 0.16 & 0.0273 & 0.34 & 0.16 & 0.0330 & 0.31 & 0.20 & 0.1116 \\
\hline 2 or more & 0.99 & 0.31 & 0.0012 & 1.00 & 0.32 & 0.0015 & 0.64 & 0.29 & 0.0251 \\
\hline
\end{tabular}

\begin{tabular}{lcccc}
\hline Pregnancy & & & & \\
Singleton (ref) & Ref & & \\
Twins or more & 1.33 & $0.21<0.0001$ \\
\hline
\end{tabular}

Proximal level

APGAR score in the

fifth minute

\begin{tabular}{|c|c|c|c|}
\hline 0 to 3 & Ref & & \\
\hline 4 to 7 & -1.24 & 0.53 & 0.0190 \\
\hline 8 to 10 & -3.13 & 0.49 & $<0.0001$ \\
\hline
\end{tabular}

Weight of the child at birth (g)

Less than 1,000

1,000 I $-1,499$

$1,500 \mathrm{I}-2,500$

$2,500 \mathrm{I}-4,000$

4,000 or more

Adjustment of the model $(\mathrm{QIC})^{\mathrm{c}}$

Ref: reference

a SE: Standard error of estimate.

' Ref: reference level. The reference level of the dependent variable (preventable child death) was the category "yes".

${ }^{c}$ QIC Statistics: quasi-likelihood under the independence model criterion. (in minimum wages) remained in the multiple regression model $(\mathrm{p}<0.0001)$. In model 2 , which included the intermediate level I (the characteristics of the mother), the following variables remained: average income of the neighborhood of the mother $(\mathrm{p}<0.0001)$, age group of the mother $\leq 19$ years $(p<0.0001)$, mothers with four or more children $(p=0.0001)$, mothers with one dead child ( $p=0.0219)$, and mothers with two or more dead children $(\mathrm{p}=0.0017)$. In model 3 , which included the intermediate level II and the studied variables related to prenatal care and delivery, the variables that remained were those concerning the average income of the neighborhood of the mother $(\mathrm{p}<0.0001)$, the age of the mother $\leq 19$ years $(\mathrm{p}<0.0001)$, mothers with four or more living children ( $p=0.0001)$, mothers with one dead child $(p=0.0260)$, mothers 
with two or more dead children ( $\mathrm{p}=0.0017$ ), and mothers pregnant with more than one child $(p<0.0001)$. After adjusting the four hierarchical levels, the variables that were part of the final model were: a) distal level (block I): average income of the neighborhood of the mother ( $<$ $0.0001)$; b) intermediate level I (block II): mothers aged $\leq 19$ years $(\mathrm{p}<0.0001)$, mothers with one to three alive children $(\mathrm{p}=0.0028)$, mothers with four or more alive children $(\mathrm{p}<0.0001)$, and mothers with two or more dead children ( $\mathrm{p}=0.0249)$; and, $c$ ) proximal level (block IV): newborns with low APGAR score $(p<0.0001)$ and low birth weight $(p<0.0001)$. From the analysis of the hierarchical multiple logistic regression, we can state that children whose mothers were aged $\leq 19$ years $(p<0.0001)$, lived in neighborhoods with average income of less than 4 minimum wages ( $p<0.0001)$ per family, $(p<0.0001)$, had one to three alive children $(p=0028)$, had four or more alive children $(p<0.0001)$, had two or more dead children $(p=0.0249)$, had children whose APGAR score in the fifth minute was low $(\mathrm{p}<0.0001)$, and had children with low birth weight $(p<0.0001)$ had higher chances of preventable child mortality.

\section{DISCUSSION}

In pregnant women care, aspects concerning the early detection of pregnancy, the access to health services, and mother and child care need to be considered ${ }^{12}$. The work with partnerships established by horizontal care for pregnant women and children, outpatient care (e.g., child health days, facility care, and emergency transport), equipped hospitals, and prepared teams would help reducing child mortality ${ }^{18,19}$. Our study showed that 73 children $(26.8 \%)$ would not have died if their mothers had received better care during pregnancy, $60(22.1 \%)$ would not have died if they had the help of (intersectoral) partnerships, 42 (15.4\%) if they had appropriate care at delivery, and one $(0.4 \%)$ if there was the chance to receive immunoprevention.

Regarding the underlying causes of preventable deaths, this study showed that 96 (35.3\%) children from 272 deaths may not have died if, during prenatal care, mothers had had the chance of being diagnosed and treated for possible complications at the right time, and the main causes of death were related with maternal conditions that occurred during pregnancy, such as hypertension, urinary tract infection, vaginosis, gestational diabetes, or previous diabetes, corroborating with other scientific studies ${ }^{12,20}$. The impact of actions to end preventable infant deaths is high and the cost is low ${ }^{19}$.

Our study showed that, before the first year of life, children will have more chances of dying if their mothers fit at least one of the following criteria: live in neighborhoods with an average family income of $<4$ minimum wages, aged $\leq 19$ years, have one or more alive children, and have two or more dead children. When it comes to the children's own characteristics, newborns will have more chances of dying if they are born with low APGAR score at the fifth minute and low birth weight $(<2,500 \mathrm{~g})$.

In the city of Piracicaba, even with the expansion of the Health Family Program and the greater technological adequacy of health services in secondary levels, the neonatal death rate still remains high, accounting for $69.5 \%$ of all child deaths (51.8\% having died before six days of age), according to several studies in the literature ${ }^{1,20-22}$. Concerning the post-neonatal component, the proportion of deaths was $30.5 \%$, and the main causes of death could also be prevented with early diagnosis and treatment. These causes are associated with respiratory disorders, epileptic syndrome, and infectious diseases, especially the ones acquired in the hospital environment when the period of hospitalization is extended ${ }^{23}$.

The literature discusses the causes of preventable death according to age group, sex, socioeconomic factors, the analysis of the impact of different prevention levels, and its reduction among different locations or ethnic groups ${ }^{1}$. In this study, we used the model of hierarchical multilevel analysis, analyzing its independent variables and composing hierarchical levels from distal to proximal events regarding child mortality. Higher risk factors of preventable child mortality are part of chains of cause and effect, in which only one chain could be enough for the occurrence of child death ${ }^{12,24}$. 
In the block of sociodemographic factors, the variable "mothers who live in neighborhoods with average income of less than 4 minimum wages per family" was the only one associated with death that remained in the final model. The association between child death and low income has been discussed in the literature, showing that a country can overcome social inequalities with policies that promote a better distribution of wealth ${ }^{8,10}$. Thus, preventable causes of death with high rates of risk represent a problem in less fortunate groups and there is an ethical requirement to obtain evaluation criteria to solve this problem ${ }^{10,24,25}$. The socioeconomic condition of the mother has been considered as the factor of highest positive effect in reducing child mortality, followed by factors regarding care and demographic transition, all part of maternal characteristics ${ }^{2,25}$.

In this study, the children of teenage mothers, aged $\leq 19$ years, have higher chances of preventable child death. Teen pregnancy concentrates the worst damage to the health of the mother and perinatal complications, which can worsen in precarious socioeconomic and geographical situations, with difficulties in the access to health services and with the presence of family issues ${ }^{23}$. Women of low socioeconomic level get pregnant early and have difficulties while taking care of newborns, since poverty and teen pregnancy are indicators of precarious life conditions and lack of prenatal care ${ }^{26}$.

Another study has shown that the lower the age of the mother, the greater are the death trends in the first year of life of the children, especially concerning postnatal deaths, associated with newborn care ${ }^{26}$. Therefore, teenagers need to be taken care of differently, with a multidisciplinary team to ensure that multifactorial demands are understood. The support to families and teenagers with an intersectoral network of health care becomes essential for the adequate care of mothers and children ${ }^{26}$.

In this study, mothers with one or more alive children had higher chances of preventable child death, corroborating another study that has reported higher prevalence of child death among mothers with four or more children ${ }^{23}$. In addition, mothers with two or more dead children were also significantly associated with preventable death. Abortions and early fetal deaths have been associated with a higher prevalence of child deaths ${ }^{22,25}$.

In the final model, low APGAR scores in the fifth minute and low birth weight showed association with preventable child death, corroborating studies found in the literature and supportting its continued usefulness in contemporary practice ${ }^{20,27-29}$. Premature newborns have a ten times higher chance of death because of complications regarding longer permanence in the hospital or the undevelopment of the neurological and respiratory systems ${ }^{22,25,30}$.

In this context, the risk factors highlighted in this study indicate the need for actions that improve the planning of prenatal care by detecting and treating pregnancy difficulties at the right moment and taking care of women since the beginning of gestation with the help of all offered services, in addition to, the development of horizontalized health care networks, the broadening of points of view on social inequalities, the planning of different actions for teenage groups, multiparous women, and women with previous dead children, and the development of actions that omprove the prenatal care, which can contribute to reduce preventable child deaths.

Finnaly, our study has some limitations. This was a cross-sectional study that sought inferences regarding causal factors without, however, establishing a temporal relationship. Furthemore, data was manually collected by specialized and trained technicians. However, despite the process of conferencing, the human factor can be considered a limitation of the study.

In conclusion, the following characteristics of the mother are determinant for the higher mortality of children before the first year of life: living in neighborhoods with an average family income lower than four minimum wages, being aged $\leq 19$ years, having one or more alive children, having children with low APGAR level at the fifth minute of life, and having low birth weight $(<2,500 \mathrm{~g})$. 


\section{REFERENCES}

1. Ortiz LP. O modelo de riscos competitivos no estudo da mortalidade infantil. In: Anais do 11. Encontro Nacional de Estudos; 1998; Belo Horizonte, MG. Campinas: ABEP; 1998 [

2. Mathias TAF, Assunção AN, Silva GF. Óbitos infantis investigados pelo Comitê de Prevenção da Mortalidade Infantil em região do Estado do Paraná. Rev ESC Enferm USP. 2008;42(3):445-53. https://doi.org/10.1590/S0080-62342008000300005

3. Drumond EF, Machado CJ, França E. Óbitos neonatais precoces: análise de causas múltiplas de morte pelo método Grade of Membership. Cad Saude Publica. 2007;23(1):157-66. https://doi.org/10.1590/S0102-311X2007000100017

4. Rede Interagencial de Informações para a Saúde. Indicadores básicos para a saúde no Brasil IDB 2011. Brasília (DF): RIPSA; 2012.

5. Duarte CMR. Reflexos das políticas de saúde sobre as tendências da mortalidade infantil no Brasil: revisão da literatura sobre a última década. Cad Saude Publica. 2007;23(7):1511-28. https://doi.org/10.1590/S0102-311X2007000700002

6. Ferrari LSL, Brito ASJ, Carvalho ABR, Gonzáles MRC. Mortalidade neonatal no Município de Londrina, Paraná, Brasil, nos anos 1994, 1999 e 2002. Cad Saude Publica. 2006;22(5):1063-71. https://doi.org/10.1590/S0102-311X2006000500019

7. Rutstein DD, Berenberg W, Chalmers TC, Child CG 3rd, Fishman AP, Perrin EB. Measuring the quality of medical care: a clinical method. N Engl J Med. 1976;294(11):582-8. https://doi.org/10.1056/NEJM197603112941104

8. Guimarães TMR, Alves JGB, Tavares MMF. Impacto das ações de imunização pelo Programa Saúde da Família na mortalidade infantil por doenças evitáveis em Olinda, Pernambuco, Brasil. Cad Saude Publica. 2009;25(4):868-76. https://doi.org/10.1590/S0102-311X2009000400018

9. Nascimento RM, Leite AJM, Almeida NMGS, Almeida PC, Silva CF. Determinantes da mortalidade neonatal: estudo caso-controle em Fortaleza, Ceará, Brasil. Cad Saude Publica. 2012;28(3):559-72. https://doi.org/10.1590/S0102-311X2012000300016

10. Buss PM, Pellegrini Filho A. Iniqüidades em saúde no Brasil, nossa mais grave doença: comentários sobre o documento de referência e os trabalhos da Comissão Nacional sobre Determinantes Sociais da Saúde. Cad Saude Publica. 2006;22(9):2005-8. https://doi.org/10.1590/S0102-311X2006000900033

11. Simão R, Gallo PR. Mortes infantis em Cabinda, Angola: desafio para as políticas públicas de saúde. Rev Bras Epidemiol. 2013;16(4):826-37. https://doi.org/10.1590/S1415-790X2013000400003

12. Domingues RMSM, Hartz ZMA, Dias MAB, Leal MC. Avaliação da adequação da assistência pré-natal na rede SUS do Município do Rio de Janeiro, Brasil. Cad Saude Publica. 2012;28(3):425-37. https://doi.org/10.1590/S0102-311X2012000300003

13. Instituto de Pesquisas e Planejamento de Piracicaba. Serviço de Informação ao Cidadão. Piracicaba: IPPLAP; 2011. Available from: http://ci.pmp.sp.gov.br/sic/

14. Instituto Brasileiro de Geografia e Estatística. Censo Demográfico 2010: resultados gerais da amostra. Rio de Janeiro: IBGE; 2012 [cited 2017 Nov 30]. Available from: https://ww2.ibge.gov. br/home/presidencia/noticias/imprensa/ppts/00000008473104122012315727483985.pdf

15. Ortiz LP. Agrupamento das causas de morte dos menores de um ano segundo critério de evitabilidade das doenças. São Paulo: Fundação Sistema Estadual de Análise de Dados; 2000.

16. Lima S, Carvalho ML, Vasconcelos AGG. Proposta de modelo hierarquizado aplicado à investigação de fatores de risco de óbito infantil neonatal. Cad Saude Publica. 2008;24(8):1910-6. https://doi.org/10.1590/S0102-311X2008000800019

17. SAS Institute. SASR software: release 9.3. Cary, NC; 2010.

18. Catré D, Lopes MF, Madrigal A, Oliveiros B, Viana JS, Cabrita AS. Early mortality after neonatal surgery: analysis of risk factors in an optimized health care system for the surgical newborn. Rev Bras Epidemiol. 2013;16(4):943-52. https://doi.org/10.1590/S1415-790X2013000400014

19. Bhutta ZA, Das JK, Bahl R, Lawn JE, Salam RA, Paul VK, et al. Can available interventions end preventable deaths in mothers, newborn babies, and stillbirths, and at what cost? Lancet. 2014;384(9940):347-70. https://doi.org/10.1016/S0140-6736(14)60792-3 
20. Laurenti R, Jorge MHPM, Gotlieb SLD, Oliveira BZ, Pimentel EC. O estudo do binômio mãe-filho: descrição e resultados gerais. Rev Bras Epidemiol. 2015;18(2):398-412. https://doi.org/10.1590/1980-5497201500020009

21. Jobim R, Aerts D. Mortalidade infantil evitável e fatores associados em Porto Alegre, Rio Grande do Sul, Brasil, 2000-2003. Cad Saude Publica. 2008;24(1):179-87. https://doi.org/10.1590/S0102-311X2008000100018

22. Malta DC, Duarte EC, Escalante JJC, Almeida MF, Sardinha LMV, Macário EM, et al. Mortes evitáveis em menores de um ano, Brasil, 1997 a 2006: contribuições para a avaliação de desempenho do Sistema Único de Saúde. Cad Saude Publica. 2010;26(3):481-91. https://doi.org/10.1590/S0102-311X2010000300006

23. Franceschini VLC, Gomes MMF, Gonzaga MR. Vulnerabilidade ao óbito infantil: uma análise do perfil dos nascidos vivos segundo as microrregiões do Vale do Jequitinhonha, 2007. In: Anais do 17. Encontro Nacional de Estudos Populacionais; 2010; Caxambu, MG. Campinas: ABEP; 2010.

24. Ortiz LP. Agrupamento das causas evitáveis de morte dos menores de um ano segundo critério de evitabilidade das doenças. São Paulo: Fundação SEADE; 2000.

25. Hartz ZMA, Champagne F, Leal MC, Contandriopoulos AP. Mortalidade infantil "evitável" em duas cidades do Nordeste do Brasil: indicador de qualidade do sistema local de saúde. Rev Saude Publica. 1996;30(4):310-8. https://doi.org/10.1590/S0034-89101996000400004

26. Oliveira EFV, Gama SGN, Silva CMFP. Gravidez na adolescência e outros fatores de risco para mortalidade fetal e infantil no Município do Rio de Janeiro, Brasil. Cad Saude Publica. 2010;26(3):567-78. https://doi.org/10.1590/S0102-311X2010000300014

27. Drumond EF, Machado CJ, França E. Óbitos neonatais precoces: análise de causas múltiplas de morte pelo método Grade of Membership. Cad Saude Publica. 2007;23(1):157-66. https://doi.org/10.1590/S0102-311X2007000100017

28. Carniel EF, Zanolli ML, Antônio MARGM, Morcillo AM. Determinantes do baixo peso ao nascer a partir das Declarações de Nascidos Vivos. Rev Bras Epidemiol. 2008;11(1):169-79. https://doi.org/10.1590/S1415-790X2008000100016

29. Iliodromiti S, Mackay DF, Smith GC, Pell JP, Nelson SM. Apgar score and the risk of causespecific infant mortality: a population-based cohort study. Lancet. 2014;384(9956):1749-55 https://doi.org/10.1016/S0140-6736(14)61135-1

30. Araújo BF, Tanaka ACA. Fatores de risco associados ao nascimento de recém-nascidos de muito baixo peso em uma população de baixa renda. Cad Saude Publica. 2007;23(12):2869-77. https://doi.org/10.1590/S0102-311X2007001200008

Authors' Contribution: Design and planning of the study: SMCVS, RAT. Collection, analysis, and interpretation of the data: KLC, GMBA. Preparation or review of the study: LFP, BVCG. Critical review of the study: ACP, MCM. Approval of the final version: SMCVS, RAT, KLC, GMBA, LFP, BVCG, ACP, MCM. All authors assume public responsibility for the content of the article.

Conflict of Interest: The authors declare no conflict of interest. 